\title{
Impact of industrial effluent from an iron and steel company on the physico- chemical quality of Kwekwe River water in Zimbabwe
}

\author{
Jonathan R. Chinhanga \\ Department of Food Science and Post Harvest Technology, Chinhoyi University of Technology, P. Bag 7724, Chinhoyi, ZIMBABWE \\ E-mail: jchinhanga@cut.ac.zw, Tel +26367 28947, Fax +26367 23726, Cell: +263 913668875
}

\begin{abstract}
The concentrations of heavy metals in bank soils, bed sediments and water of Kwekwe River, upstream and downstream of the industrial effluent discharge point were examined with the aim of determining the effect of the effluent on the river water quality. Five sampling sites were selected along the river and samples were collected between April and June 2005. Water variable characteristics data were analysed for variations using one-way analysis of variance (ANOVA). Hierarchical method, average linkage cluster analysis was applied to the mean values of the water variables for each site. Two clusters were produced, grouping the reference site and two furthest sites downstream of the effluent discharge point. Water physico-chemical variables and heavy metals changed remarkably at downstream $(\mathrm{p}<0.05)$. Calcium and iron proved to be the most metals influencing the river water quality with accumulation factors of 6.1 and 7.8, respectively in the sediments. The concentrations of cations were higher in sediments than those in bank soils at sites downstream of the discharge point. The river had the highest selfpurification amounts with respect to total dissolved solids. The results of the study proved deterioration of Kwekwe River water quality due to the discharged effluent.
\end{abstract}

Keywords: Physico-chemical variables, sediments, river water quality, industrial effluent

\section{Introduction}

Despite a variety of alternatives available for industrial wastewater management, many industries continue to degrade the most precious but scarce natural resource. One out of three people in the developing countries does not have access to safe drinking water and some 123 freshwater animal species have gone into extinction in North America (Smol, 2002). Quite a number of industries in developing countries still use either outdated or the least practicable technologies due to economic constrain (Fakayode, 2005). The Dublin Principles, Agenda 21, Vision 21 and the Millennium Development Goals, for example, provide the basis for development of holistic and sustainable approaches (Nhapi, 2005), but project proponents continue degrading the aquatic ecosystems. The fundamental importance of freshwater for life on the earth needs little justification. It is a limiting factor for industrial development and irrigation of crops (Gleick, 1993; Falkenmark et al., 1998). Water is a fundamental force in ecological life-support systems on which sustainable social and economic development depend (Hirji et al., 2002; Rockstrom et al., 1999). Studies have shown that water quality in aquatic ecosystems has a strong ecological impact (Harding et al., 1999; Ometo et al., 2000).

Freshwater is not only essential to life, but also clearly a relatively scarce resource and this is likely to become more so with the impacts of climate change. Climate change will influence the effects from which chemical pollutants as increased temperatures are likely to increase the biochemical rates and biomagnifications of toxicants. According to Matiza et al. (2002 cited in Hirji et al., 2002), the southern African region is expected to be drier by the year 2025. Predictions are that Lesotho, Mauritius, Tanzania and Zimbabwe will be water stressed, while Malawi and South Africa will face absolute water scarcity. Climate change rainfall scenarios also suggest that annual rainfall will decrease by up to $5 \%$ and this will be experienced in Namibia, Mozambique and parts of Zimbabwe and South Africa (Hirji et al., 2002).

The costs of correcting degraded water and dealing with unforeseen conflicts over water shortages may be very high for future generations to come. An estimated $25 \%$ of the world's food market is driven by water scarcity (Postel, 1998). There has been 
concern in Zimbabwe about the health of Kwekwe River due to effluents being discharged into the river by a Kwekwe-based iron and steel company. The Kwekwe-based iron and steel company discharged high quantities of iron, sulphate, oil and tar into Kwekwe River, making the water unsuitable for irrigation and domestic use (Moyo et al., 1998).

Zimbabwe's water resources are under increasing threat of pollution due to discharge of partially or an untreated industrial effluent (personal observation), Kwekwe River is not an exception. No studies have been done to assess the ecological health of the river, despite numerous complaints from Kwekwe residents concerning the health of the river due to effluents being discharged into it by the Kwekwe-based steel company.

Fears have been raised that due to the discharges from the Kwekwe-based steel company, the river could be polluted excessively. The need to assess the state and quality of Kwekwe River water becomes imperative given that the water is used for domestic use, irrigation and livestock rearing. The river is of importance not only to people who live, fish and farm in Kwekwe town but also to citizens in faraway towns, who consume fish from the river.

\section{Materials and Methods}

\section{Description of study area}

The study area is located in the Midlands province of Zimbabwe, covering a $12 \mathrm{~km}$ stretch of Kwekwe River. The town lies $18^{\circ} 92^{\prime} \mathrm{S}, 29^{\circ} 81^{\prime} \mathrm{E}$ and $1200 \mathrm{~m}$ above sea level. The town is located $213 \mathrm{~km}$ south-west of the capital city of Zimbabwe, Harare (Figure 1). Kwekwe town receives mean annual rainfall of between 600 and $699 \mathrm{~mm}$ (Chenje, 2000). Redcliff, located in the town of Kwekwe, is the iron and steel-producing centre of Zimbabwe.

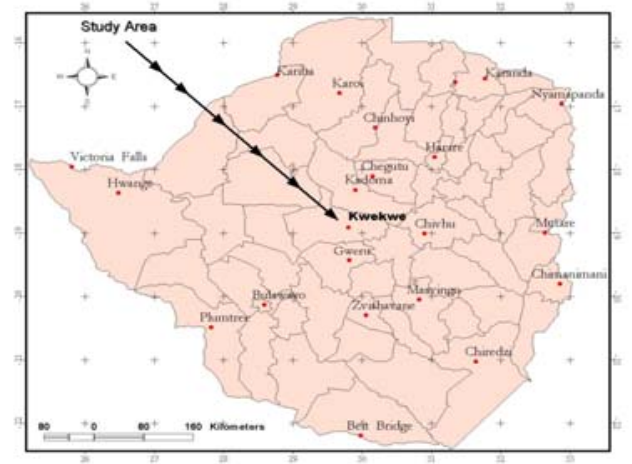

Figure 1. Map of Zimbabwe

Kwekwe River is a perennial river, originating from Whitewaters Dam in Chiwundura and flows through the town of Kwekwe. It stretches for about 78km into Sebakwe River, which connects it into Munyati River. Munyati River flows into Lake Kariba, which subsequently drains into Zambezi River. The geology of the catchment is mainly limestone, basaltic and peridotitic, metavolcanics and metasediments (Cheshire et al., 1980). The oldest rocks in the study area belong to the Sebakwian group, occurring as inclusions, composed of ironstones and various ultramafic rocks within the granite batholiths along the western margin of the greenstone belt (Cheshire et al., 1980). Kwekwe River flows for the greater part along direct courses over granitic rock, but forms meanders on approaching the belt and subsequently breaks through jaspilite ridge in the gorge at Cactus Poort (Cheshire et al., 1980). Kwekwe River serves not only as one of the drainage for Midlands region, but also provides water for domestic and industrial use, irrigation and a conduit for effluent disposal in Kwekwe town.

\section{Sampling procedure}

Guided by a geographical positioning system (GPS), sampling sites were systematically located and were chosen due to their easy accessibility and representativeness of the affected part of the river. A $20 \mathrm{~m}$ stretch of the river channel was examined for each site on each occasion to evaluate the environmental impact of the effluent (Kwe X) from the Kwekwe-based steel company on Kwekwe River. Only one sampling site, Kwe1, was located as a reference point; Kwe 2 was the point of effluent discharge, Kwe 3-5 were downstream sites of the discharge point with Kwe 5 being the furthest.

The study was conducted when the country as a whole had received low rainfall in the preceding rainy season, for the period April through June 2005. Sampling followed standard cleaning protocols, which involved cleaning of sampling equipment between sampling sites to avoid cross-contamination of samples with heavy metals. Water, soil and sediments samples were collected from the river following standard procedures described in the sampling guide (DWAF, 1992; 1999). Three sample points were randomly chosen on each occasion at each site. 


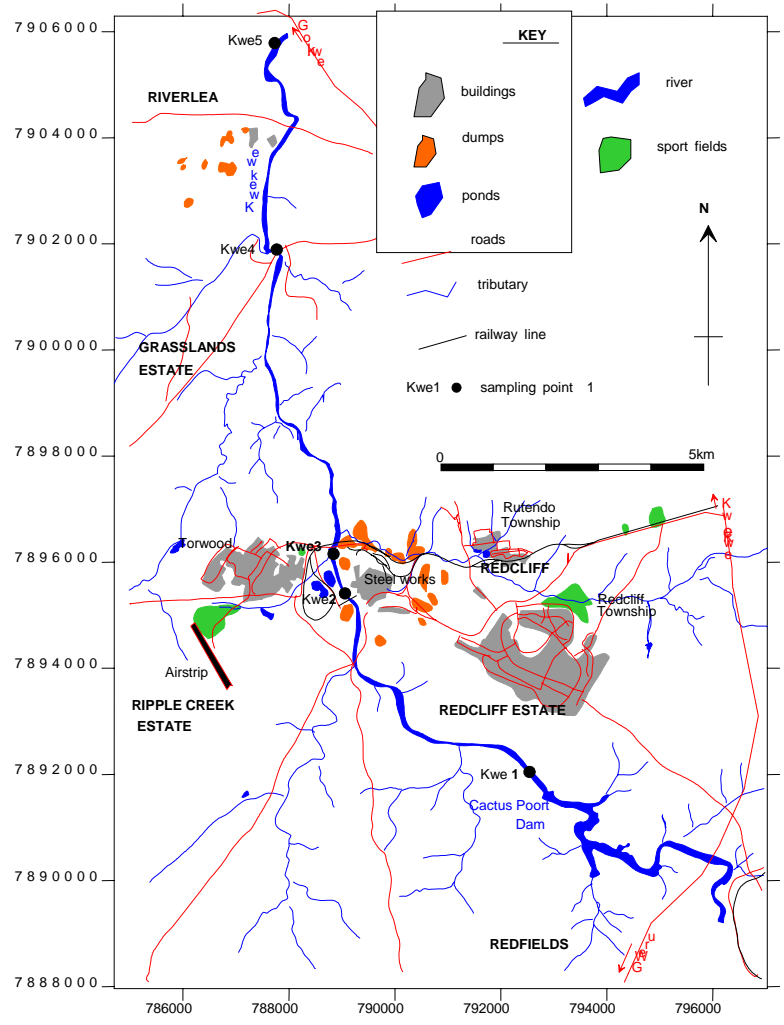

Figure 2. Study area map showing sampling sites along Kwekwe River

\section{Physico-chemical variables}

Physico-chemical variables were examined at 3 occasions from April to June 2005. Dissolved oxygen, pH, conductivity and temperature of the water were measured electrometrically on site using WTW Oxi 330 meter, WTW pH 330 meter and WTW LF 330 meter, respectively. Turbidity was subjectively assessed as high, medium or low. Total dissolved salts (TDS), were determined by filtering $100 \mathrm{ml}$ of water and then evaporating it gradually in pre-weighed crucibles. The change in weight was used to determine the dissolved salts. Chemical oxygen demand (COD) was determined by titration method, using ferrous ammonia sulphate and ferroin as indicator (APHA et al., 1992).

The amounts of self-purification were measured between two sampling sites, namely Kwe 2 (point of effluent discharge) and Kwe 5 (11.46 Km downstream of Kwe 2). The degree of contamination as a result of effluent discharge was estimated by the accumulation factor (AF), which is the ratio of the average level of a given variable downstream after the point of effluent discharge to the corresponding average level upstream (Fakayode, 2005). Velocity at each sampling site was estimated by measuring the time taken by a leaf to float to a distance of $10 \mathrm{~m}$. According to Allan (1995), a float gives a rough measure of surface velocity. The average river depth at each site was determined by taking 5 measurements at $1 \mathrm{~m}$ intervals across the river channel. Average river discharge (r) at each site was calculated using the formula: $r=W d v a$ (Welch, 1948)

Where; * ${ }^{*}$ is average rate of flow in $\mathrm{m}^{3} \mathrm{~s}^{-1}$; $\mathrm{W}$ is average width of the river channel at the sampling site in meters; $\mathrm{v}$ is average velocity in $\mathrm{m} \mathrm{s}^{-1}$ at the sampling site; $\mathrm{d}$ is average depth of the river channel at the sampling site; $\mathrm{a}$ is a constant and is 0.9 when the river bed is smooth and composed of such material as sand, mud or hard pan; and $a=0.8$ when the river bed is composed of loose rocks and coarse gravel (Welch, 1948).

\section{Water Chemistry}

Water samples were collected at random in triplicate within a distance of $15 \mathrm{~m}$, at the centre of the river channel at each site on 3 occasions from April to June 2005. The samples were collected using $500 \mathrm{ml}$ polythene bottles. The bottles were thoroughly cleaned in soap solution first, soaked in $10 \%$ hydrochloric acid ( $\mathrm{HCl})$ for 24hrs, and then rinsed with deionised water. The bottles were further rinsed three times with sample water, immersed about $20 \mathrm{~cm}$ (Downson et al., 1996) below the water surface and filled to the brim. All samples were tightly sealed and kept cool using ordinary dry ice in the field and while on transit to the laboratory. Immediately upon arrival at the laboratory, all water samples for heavy metal and anion analysis were filtered through 
0.45micron-pore-diameter filter and preserved by adding $0.3 \mathrm{ml} 65 \%$ nitric acid $\left(\mathrm{HNO}_{3}\right)$ to a pH below 2 and stored at $4{ }^{\circ} \mathrm{C}$ until analysis. The samples were analysed for iron, manganese, calcium, cadmium, chromium, lead, zinc, sulphates, phosphates, nitrates and ammonia.

The concentrations of the heavy metals and anions in the samples were determined according to standard procedures (APHA et al., 1989). The concentrations of the heavy metals were determined by using atomic absorption spectrophotometer (AAS). Ammonia, phosphate and nitrate ions were determined by the methods of Madêra et al., (1982). Ammonia was determined calorimetrically by measuring the intensity of the blue colour produced by the reaction of dissolved ammonia in the samples with the hypochlorite in the presence of phenol. Nitrates $\left(\mathrm{NO}_{3}{ }^{-}\right)$were determined by using the chromotropic acid method based on measuring the intensity of the yellow colour produced by the reaction of $\mathrm{NO}_{3}{ }^{-}$ions with phenoldilsulphonic acid. Total phosphate $\left(\mathrm{PO}_{4}{ }^{3-}\right)$ was determined spectrophotometrically by measuring the intensity of the blue colour produced in the reaction between phosphate and ammonia molybdate in the presence of amonoaphtholsulphonic acid, a reducing agent. The concentration of sulphates $\left(\mathrm{SO}_{4}{ }^{2-}\right)$ in water samples was determined by using the turbidimetric procedures based on the precipitation of sulphate from the water using a conditioning reagent and barium chloride dihydrate.

\section{Soil (river bank sediments) and Sediment (river bed) Chemistry}

Soil and sediment samples were randomly collected on two different occasions in April and June 2005. Triplicate samples were taken at each site and then pooled in a polythene bag. Soil samples were taken from the surface of riverbanks at each site using a garden trowel. A core sampler was used to collect sediments from the riverbed at each site to a depth of $5 \mathrm{~cm}$. The samples were kept cool in the field and en route to the laboratory using dry ice. The samples were kept frozen in the laboratory until analysis. The sediment and soil samples were allowed to defrost then air-dried at $30^{\circ} \mathrm{C}$ and thereafter sieved mechanically using a $2 \mathrm{~mm}$ sieve. The samples were subjected to a total digestion method to determine the concentrations of $\mathrm{Fe}, \mathrm{Mn}, \mathrm{Cr}, \mathrm{Cd}, \mathrm{Ca}, \mathrm{Zn}$ and $\mathrm{Pb}$ using atomic absorption spectrophotometer (APHA et al., 1989). All determinations were based on the fine sediment and soil obtained from sieving since metals adhere to these fine particles (Awofolu et al., 2005).

\section{Results and Discussion}

\section{Water chemistry of Kwekwe River}

The mean concentrations of ammonia-nitrogen and nitrate-nitrogen in the water column phase decreased with increase in distance from effluent discharge point, Kwe 2 while there was a sharp increase of ammonia-nitrogen and nitrate-nitrogen upstream of Kwe 2 (Figure 3). The mean concentrations of ammonia-nitrogen and nitrate-nitrogen were high in the industrial effluent, Kwe X.

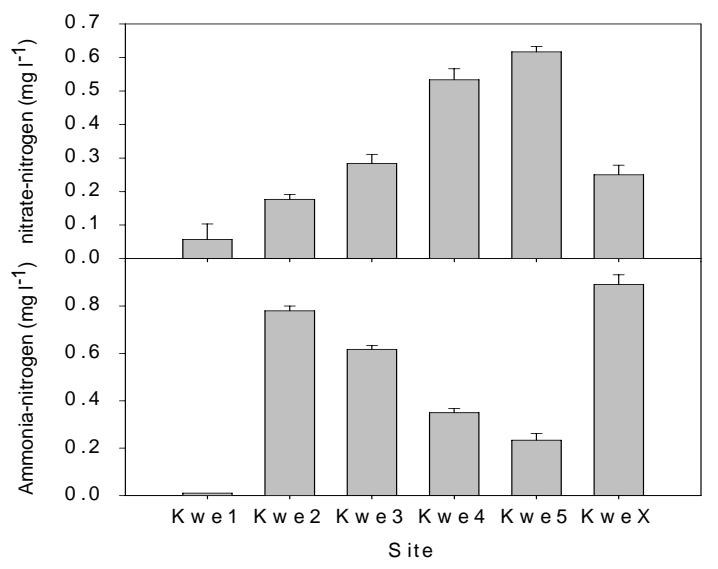

Figure 3. Mean \pm (SE) concentrations of ammonia-nitrogen and nitrate-nitrogen in Kwekwe River and effluent (Kwe X)

The reduction in ammonia-nitrogen concentrations at Kwe4 and Kwe5 may be explained by the observed increase in dissolved oxygen (Figure 9). In the presence of oxygen, ammonia is oxidised to nitrate ions. This may also explain the observed increase in nitrate ions downstream of the effluent discharge point. The reduction of ammonia downstream of the effluent discharge point may also be attributed to the fact that at high $\mathrm{pH}$, most ammonia will be in gaseous state, therefore, the gas volatilises as the river flows. 


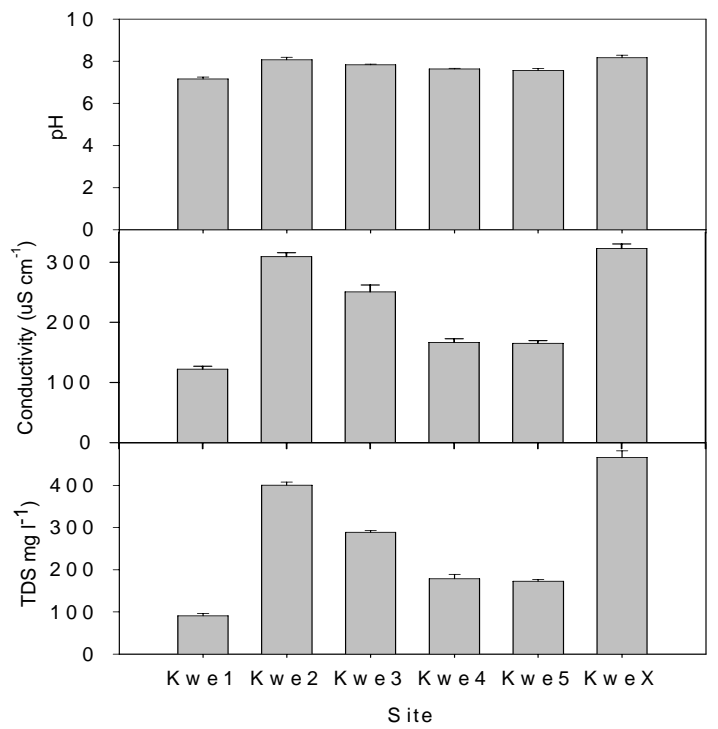

Figure 4. Mean \pm (SE) concentrations of TDS and conductivity in Kwekwe River and effluent (Kwe X)

The mean TDS and conductivity decreased with increase in distance from the effluent discharge point while the mean pH levels measured at sites downstream of the effluent discharge point varied between 7.6 and 7.8 (Figure 4). The mean $\mathrm{pH}$ values are typical of tropical rivers (Moyo and Worster, 1997). Mean conductivity levels at site Kwe2 and Kwe 3 were above the maximum prescribed limits for Zimbabwe's raw water (Government of Zimbabwe, 2000) and were highest for the effluent (Figure 4). The sharp increase in conductivity between site Kwe1 and Kwe 2 corresponded to the observed increase in total dissolved solids (Figure 4). Conductivity is proportional to the ionic concentration, which is a result of the dissolved solids. The higher reading at Kwe2 was probably due to the effluent and the decrease downstream may be a sign that ions were precipitating out settling on the riverbed or being absorbed by aquatic plants. The gradual decrease in total dissolved solids after site Kwe3 and the corresponding decrease in conductivity may be attributed to the salting-out of the dissolved salts from the water-column phase and the subsequent settling at the riverbed. The reference site, Kwe1 was shown to be significantly $(\mathrm{p}<0.05)$ different from downstream sites of the effluent discharge point. The presence of the cations and anions in water at Kwe1 may be attributed to natural phenomena such as weathering of rocks and soils, and not to anthropogenic activities.

The mean concentrations of sulphate were very low and decreased at downstream sites of Kwe 2. The average concentrations of total phosphorus decreased with increase in distance from Kwe 2. Highest mean levels of sulphate and total phosphorus were recorded for the industrial effluent, Kwe X (Figure 5). The low levels of sulphates may be attributed to the co-precipitation of sulphates with metal ions. The mean values of water quality variables at site Kwe1 were all below the maximum prescribed limits set for Zimbabwe's raw water (Government of Zimbabwe, 2000), further suggesting that the river was slightly disturbed at this site.

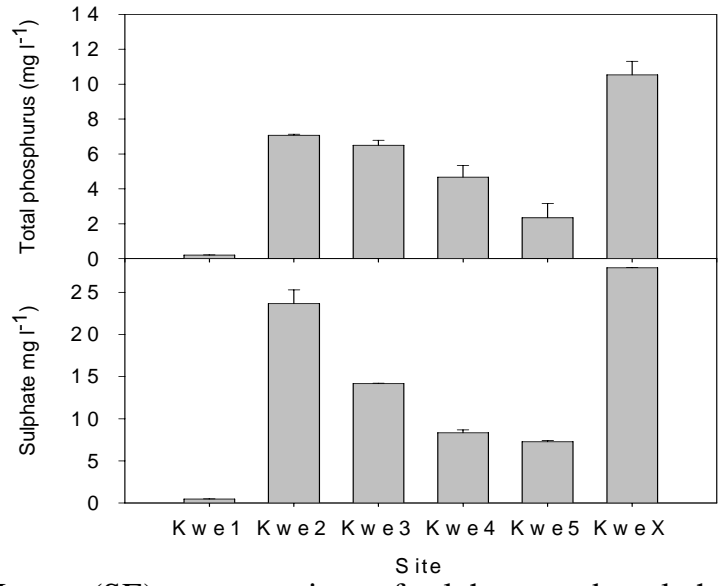

Figure 5. Mean \pm (SE) concentrations of sulphates and total phosphorus in Kwekwe River and industrial effluent (KweX) 
High chromium and calcium levels were recorded for downstream sites of the effluent discharge point (Figure 6), in contrast with the low levels at Kwe1, suggesting possible water contamination at downstream sites.

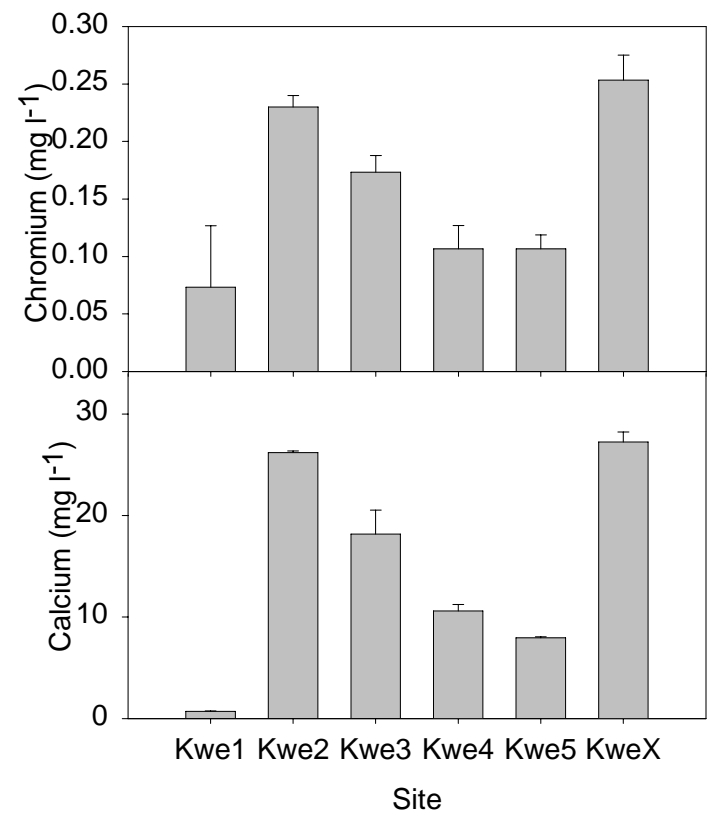

Figure 6. Mean \pm (SE) concentrations of calcium and chromium in Kwekwe River, also shown is the level of these heavy metals in the effluent (KweX)

The levels of manganese decreased slightly downstream of the discharge point (Figure 7). The decrease of the cations and anions observed at downstream sites of the effluent discharge point may be attributed to precipitation and co-precipitation of these ionic species.

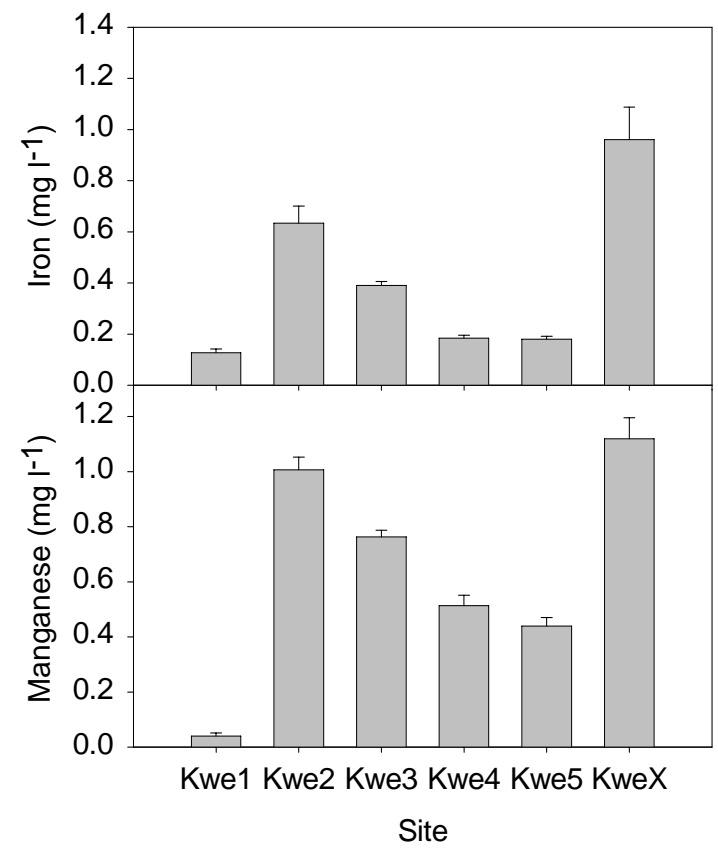

Figure 7. Mean \pm (SE) concentrations of iron and manganese in Kwekwe River industrial effluent (KweX) 
According to Hoehn and Sizemore (1977) manganese precipitates at pH above 10. Manganese, can, therefore, be carried for long distances downstream of a source. The high levels of cations and anions recorded for site Kwe2 were not consistent with the high pH levels measured at this site. This is so, for at high pH, iron is expected to precipitate (Maine et al., 2004; Schmitz (1996). Dissolved cations may co-precipitate when ferric hydroxide flocs form, therefore, the decrease in iron concentrations at sites Kwe4 and Kwe5, may be attributed to its co-precipitation with reactive soluble phosphorus (Maine et al., 2004). Phosphate complexes with heavy metals and insoluble precipitates are produced. The high levels of cations at Kwe2 were probably due to the fact that the elements were in suspension when the water samples were collected for analyses.

The calculated discharge rate at each of the five sites showed no pattern, with site Kwe 4 having the highest mean discharge rate. The highest mean velocity was recorded at the upstream site, Kwe 1, after which it decreases gradually downstream of the river (Figure 8). Chemical Oxygen demand (COD) changed remarkably downstream of the discharge point $(\mathrm{p}<0.05)$. Dissolved Oxygen increased with increase from the discharge point and there was slight variation between sites in the mean temperature levels, ranging between $22.6{ }^{\circ} \mathrm{C}$ and $23.7{ }^{\circ} \mathrm{C}$ (Figure 9). The temperature levels were consistent with permissible limits set for Zimbabwe's raw water (Government of Zimbabwe, 2000). The highest mean temperature of $24.8^{\circ} \mathrm{C}$ was recorded for the effluent. This may be attributed to exothermic reactions taking place between the ionic species.

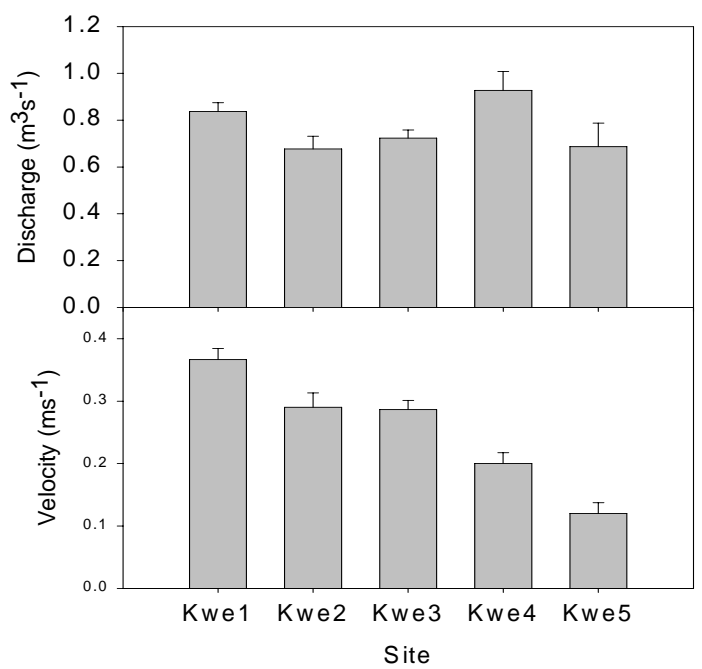

Figure 8. Mean \pm (SE) velocity and discharge of 5 sites along Kwekwe River

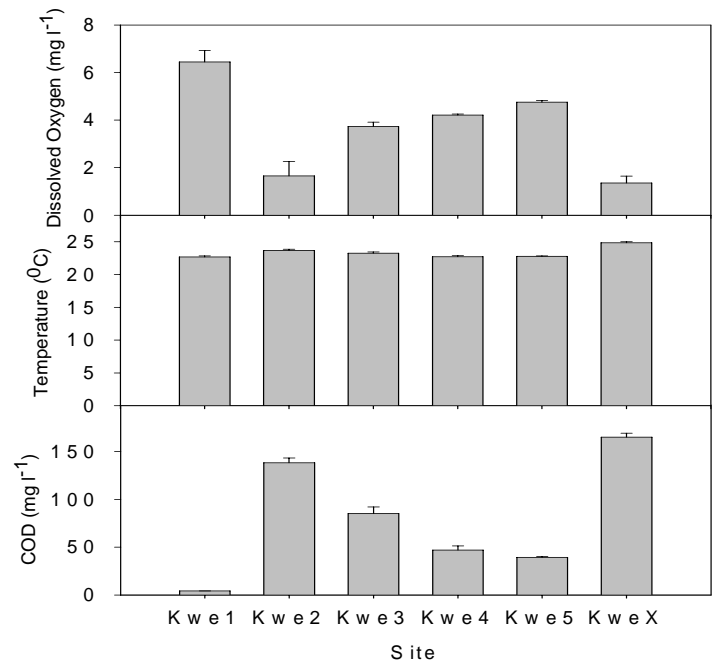

Figure 9. Mean \pm (SE) chemical oxygen demand (COD), temperature and dissolved oxygen demand along 
Kwekwe River and for the discharged effluent (KweX)

The difference in the mean levels of water quality variables between the sites was significant $(\mathrm{p}<0.05)$, as indicated by the $\mathrm{p}$ values, with the exception of discharge (Table 1).

Table 1. One-way analysis of variance for water quality variables in Kwekwe River

\begin{tabular}{|c|c|c|}
\hline Variable & $\mathrm{F}$ & $\mathrm{P}$ \\
\hline $\mathrm{pH}$ & 17.38 & 0 \\
\hline temperature & 8 & 0.004 \\
\hline conductivity* & 97.51 & 0 \\
\hline DO & 23.85 & 0 \\
\hline COD & 141.33 & 0 \\
\hline $\mathrm{NH}-\mathrm{N}$ & 261.13 & 0 \\
\hline $\mathrm{Cr}$ & 5.34 & 0.015 \\
\hline $\mathrm{Ca}$ & 78.58 & 0 \\
\hline $\mathrm{Fe}^{*}$ & 7.61 & 0.004 \\
\hline Mn & 125.21 & 0 \\
\hline $\mathrm{SO}_{4}^{2-}$ & 133.43 & 0 \\
\hline $\mathrm{NO}_{3}^{-}$ & 61.88 & 0 \\
\hline tot. $\mathrm{PO}_{4}^{3-}$ & 33.83 & 0 \\
\hline TDS & 311.76 & 0 \\
\hline Velocity & 27.12 & 0 \\
\hline discharge** & 2.61 & 0.1 \\
\hline
\end{tabular}

${ }^{*} \log _{10}(\mathrm{x}+1)$ transformed, ** not significant.

Two clusters were obtained, A and B (Figure 10). The clusters were identified at the linkage level of approximately 63\%. Group A consists of Kwe 2 (point of effluent discharge) and Kwe 3 (800m from Kwe 2) and group B consists of Kwe 1 (reference site), Kwe 4 and Kwe 5 (12 and 15 km, respectively, from Kwe 2). Thus, the water quality at the reference site, Kwe 1 was similar to sites furthest from the effluent discharge point. The calculated amounts of self-purification (Table 6), together with high levels of cations in the sediments, indicated that the river had high self-purification capacity.

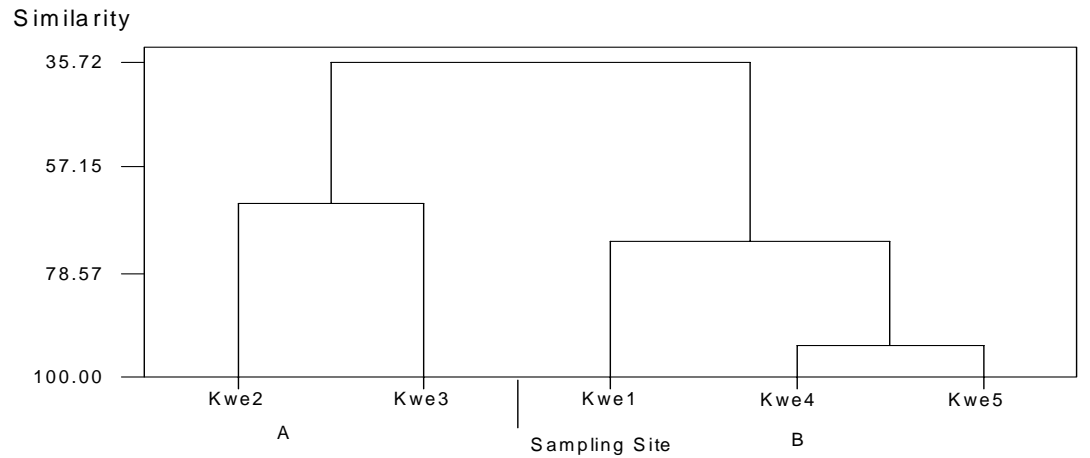

Figure 10. Dendrogram results of hierarchical average linkage cluster analysis of the water quality variables' mean values for each site

Mean levels of cations in sediments and bank soils decreased with increase in distance from the discharge point, as shown in Table 2 and 3. At site Kwe 1, levels of the cations were higher in the bank soils than those in sediments, in contrast to downstream sites of the discharge point where higher levels were observed in sediments than those in bank soils. The sites varied greatly $(\mathrm{p}<0.05)$ with respect to heavy metal levels in sediment and bank soils (Table 4). Sediments have been described as ready sink or reservoir of pollutants (Awofolu et al., 2005; Wrobel and Latinopoulos, 1995).The absence of Zinc, cadmium and lead in the water column phase may be due to the fact that these elements were present at very low levels below the detection limit of a spectrophotometer. 
Table 2. Mean \pm (SE) of chromium, cadmium, calcium, iron, lead, and manganese Concentrations ( $\mathrm{mg} \mathrm{l}^{-1}$ ) in river sediments

\begin{tabular}{clllll}
\hline & \multicolumn{5}{c}{ Site } \\
Variable & \multicolumn{1}{c}{ Kwe1 } & \multicolumn{1}{c}{ Kwe2 } & \multicolumn{1}{c}{ Kwe3 } & \multicolumn{1}{c}{ Kwe4 } \\
\hline $\mathrm{Fe}$ & $18.50 \pm 5.00$ & $36.50 \pm 6.50$ & $40.75 \pm 7.50$ & $27.50 \pm 5.00$ & $18.00 \pm 4.50$ \\
$\mathrm{Cr}$ & $1.85 \pm 1.00$ & $8.35 \pm 0.40$ & $9.25 \pm 0.75$ & $7.80 \pm 0.00$ & $6.1 \pm 1.00$ \\
$\mathrm{Cd}$ & $0.05 \pm 0.40$ & $0.09 \pm 0.50$ & $0.08 \pm 0.40$ & $0.06 \pm 0.10$ & $0.04 \pm 0.2$ \\
$\mathrm{Ca}$ & $8 \pm 0.00$ & $59.25 \pm 0.25$ & $70.5 \pm 2.50$ & $45 \pm 2.0$ & $30 \pm 1.00$ \\
$\mathrm{~Pb}$ & $0.2 \pm 0.00$ & $4.15 \pm 0.35$ & $1.23 \pm 0.38$ & $1.5 \pm 1.00$ & $1 \pm 0.00$ \\
$\mathrm{Mn}$ & $32 \pm 3.00$ & $63.5 \pm 3.50$ & $73.5 \pm 2.50$ & $83 \pm 0.00$ & $80.5 \pm 0.50$ \\
$\mathrm{Zn}$ & $0.13 \pm 0.08$ & $19.5 \pm 2.50$ & $2.25 \pm 0.75$ & $0.28 \pm 0.30$ & $0.3 \pm 0.00$ \\
\hline
\end{tabular}

Table 3. Mean \pm (SE) of chromium, cadmium, calcium, iron, lead, and manganese concentrations $\left(\mathrm{mg} \mathrm{l}^{-1}\right)$ in bank soils

\begin{tabular}{|c|c|c|c|c|c|}
\hline & & & Site & & \\
\hline Variable & Kwe1 & Kwe2 & Kwe3 & Kwe4 & Kwe5 \\
\hline $\mathrm{Fe}$ & $21.00 \pm 2.00$ & $48.00 \pm 1.00$ & $37.50 \pm 2.50$ & $15.15 \pm 1.50$ & $8.75 \pm 2.50$ \\
\hline $\mathrm{Cr}$ & $2.48 \pm 0.75$ & $8.83 \pm 0.40$ & $8.18 \pm 0.75$ & $6.60 \pm 0.70$ & $5.40 \pm 0.00$ \\
\hline $\mathrm{Cd}$ & $0.04 \pm 0.45$ & $0.08 \pm 0.40$ & $0.079 \pm 0.35$ & $0.04 \pm 0.30$ & $0.04 \pm 0.25$ \\
\hline $\mathrm{Ca}$ & $13 \pm 0.60$ & $9.75 \pm 1.75$ & $62 \pm 2.00$ & $34 \pm 3.00$ & $20.25 \pm 2.75$ \\
\hline $\mathrm{Pb}$ & $1 \pm 0.00$ & $8.25 \pm 0.75$ & $2.9 \pm 0.30$ & $3.85 \pm 0.15$ & $6.25 \pm 0.75$ \\
\hline $\mathrm{Mn}$ & $35.5 \pm 1.50$ & $112 \pm 3.00$ & $96.5 \pm 1.50$ & $93.5 \pm 3.00$ & $93 \pm 3.00$ \\
\hline $\mathrm{Zn}$ & $0.03 \pm 0.00$ & $6.75 \pm 1.75$ & $0.83 \pm 0.13$ & $0.08 \pm 0.01$ & $0.08 \pm 0.00$ \\
\hline
\end{tabular}

Ammonia-nitrogen was the most accumulated variable in the water-column phase at downstream sites, with an accumulation factor of 40 (Table 5) and iron was the most accumulated variable in the sediments, with an accumulation factor of 7.77 (Table 7). The calculated accumulation factors provide further evidence that the effluent was impacting heavily on the water quality of the river.

Table 4. One-way analysis of variance for heavy metal concentrations in river sediments and

\begin{tabular}{lcccc}
\multicolumn{5}{c}{ bank soils collected from each site } \\
\hline \multicolumn{1}{c}{ Variable } & $\mathrm{F}$ & $\mathrm{P}$ & \\
& Sediments & Bank soils & Sediments & Bank soils \\
\hline Chromium & 169.72 & 169.72 & 0.000 & 0.000 \\
Cadmium & 42.32 & 42.32 & 0.000 & 0.000 \\
Calcium & 267.10 & 267.10 & 0.000 & 0.000 \\
Iron & 120.65 & 120.65 & 0.000 & 0.000 \\
Lead & 8.88 & 8.88 & 0.017 & 0.017 \\
Manganese & 77.32 & 77.32 & 0.000 & 0.000 \\
Zinc & 8.4 & 52.19 & 0.078 & 0.000 \\
\hline
\end{tabular}

$\mathrm{NH}_{3}-\mathrm{N}$ was the most accumulated variable downstream of the industrial effluent (Table 5). The river had the highest amount of self-purification with respect to TDS and lowest for chromium (Table 6). Iron was the most accumulated metal in the river sediments downstream of the effluent discharge point (Table 7).

Table 5. Accumulation factors (AF) of the selected variables in the water-column phase

\begin{tabular}{lc}
\hline \multicolumn{1}{c}{ Variable } & $\begin{array}{c}\text { Accumulation } \\
\text { Factor }\end{array}$ \\
\hline Ammonia-nitrogen & 40.00 \\
Chromium & 1.86 \\
Calcium & 17.49 \\
Iron & 1.92 \\
Manganese & 14.25 \\
Sulphate & 21.19 \\
Total phosphate & 22.50 \\
Nitrate-nitrogen & 8.00 \\
Total dissolved salts & 2.35 \\
\hline
\end{tabular}


Table 6. Self-purification amounts $\left(\mathrm{mg} \mathrm{l}^{-1} \mathrm{~km}^{-1}\right)$ of the river with respect to selected water variables

\begin{tabular}{lc}
\hline \multicolumn{1}{c}{ Variable } & $\mathrm{S}_{\mathrm{m}}\left(\mathrm{mg} \mathrm{l}^{-1} \mathrm{~km}^{-1}\right)$ \\
\hline $\mathrm{NH}_{3}-\mathrm{N}$ & 0.04 \\
$\mathrm{Cr}$ & 0.01 \\
$\mathrm{Ca}$ & 1.23 \\
$\mathrm{Fe}$ & 0.03 \\
$\mathrm{Mn}$ & 0.04 \\
tot. $\mathrm{PO}_{4}^{3-}$ & 0.32 \\
$\mathrm{SO}_{4}{ }^{2-}$ & 1.10 \\
$\mathrm{NO}_{3}^{-}$ & 0.01 \\
$\mathrm{TDS}$ & 16.60 \\
\hline
\end{tabular}

Table 7. Accumulation factors (AF) of the selected heavy metals in the sediments of Kwekwe River

\begin{tabular}{lc}
\hline \multicolumn{1}{c}{ Variable } & AF \\
\hline Chromium (Cr) & 4.16 \\
Cadmium (Cd) & 1.31 \\
Calcium (Ca) & 6.06 \\
Iron (Fe) & 7.77 \\
Lead (Pb) & 6.20 \\
Manganese (Mn) & 2.47 \\
Zinc (Zn) & 7.52 \\
\hline
\end{tabular}

\section{Conclusion}

It was evident from the study that water quality in the river was severely impaired by the effluent discharged at site Kwe2 by a Kwekwe-based iron and steel manufacturing company. The sharp decrease in dissolved oxygen, increases in total dissolved solids and a corresponding increase in conductivity between the reference site, Kwe1 and Kwe2, (Figure 4) proved deterioration of water quality. The sharp decrease in dissolved oxygen between Kwe1 and Kwe2, (Figure 9) indicated the introduction of organic loads into the river, which required high levels of oxygen for chemical oxidation. The formation of ferric hydroxide, for example, decreases oxygen availability and may result in a complete blanketing of a stream bottom (Magadza and Masendu, 1986; Hoehn and Sizemore, 1977). The calculated amounts of self-purification, together with high levels of cations in the sediments, suggest that the river had high self-purification capacity.

The following recommendations are made:

1. The research findings should be used by Environmental Management Agency (EMA) in Zimbabwe to establish a baseline water quality data in Kwekwe River and used it to assess any changes in water quality.

2. Kwekwe municipality and environmental legal authorities should produce an internally cohesive institutional framework for waste water management. Kwekwe River water pollution levels could be reduced by strict enforcement of Environmental Management Act [Chapter 20:27] and waste effluent regulations; and by policing the iron and steel manufacturing company to ensure that the effluent discharged into Kwekwe River is within the permissible limits (Government of Zimbabwe, 2000). Section 61 of the Environmental Management Act gives power to the Environmental Management Agency Board to cancel an effluent discharge licence in case of violations of the provisions of the Act. Unfortunately, the Act can be likened to a lion without teeth; it introduces the Polluter Pays Principle, a most effective way of discouraging polluters from degrading the environment but it is not being effectively implemented.

3. Environmental Management Agency water scientists concentrate on collecting water samples, they should also focus on sediment analysis.

4. The capacity of Kwekwe River to purify itself should be recognised and managed to allow it to absorb the pollution load before discharging into Sebakwe River.

5. Wetlands and sponges can also be used to control pollution in Kwekwe River. In a study conducted by Magadza and Masendu (1986) along the Yellow Jacket Stream in Zimbabwe, wetlands were found to be effective water quality controllers.

\section{Acknowledgements}

Special thanks go to Professor N.A.G. Moyo for his guidance in this study. Department of Biological Sciences, University of Zimbabwe for their laboratory. My appreciation to former Department of Natural Resources staff, namely Mr. S.S. Mutanga and 
Mr. I. Dhau for their unflagging enthusiasm and company during part of the sampling period. Thanks to two anonymous reviewers who provided feedback on the manuscript.

\section{References}

Allan, A.D. 1995. Stream Ecology: Structure and Function of Running Waters. Chapman and Hall.

American Public Health Association (APHA), American Water Works Association and Water Pollution Control Federation. 1989. Standard Methods for the Examination of Water, $\left(17^{\text {th }}\right.$ Edition $)$. American Public Health Association, Washington.

APHA-AWWA-WPCS (1992). The Examination of Water and Wastewater $18^{\text {th }}$ Edition. Washington DC.

Awofolu, O.R., Mbolekwa, Z., Mtshemla, V. and Fatoki, O.S. 2005. Levels of trace metals in water and sediment from Tyume River and its effects on an irrigated farmland. In: Water SA, Vol. 31, No. 1, pp. 87-94.

Chenje, M. (Ed.). 2000. State of the Environment in the Zambezi Basin. A report by Southern African Development Community (SADC), The World Conservation Union (IUCN), Zambezi River Authority (ZRA) and Southern African Research and Documentation Center (SARDC). Maseru/Lusaka/Harare.

Cheshire, P.E., Leach, A. and Milner, S.A. 1980. The Geology of the Country between Gwelo and Redcliff. Salisbury.

Department of Water Affairs and Forestry (DWAF). 1992. Quality of Domestic Water Supplies: Sampling Guide. Department of Water Affairs and Forestry, Department of Health and Water Research Commission, Pretoria.

Department of Water Affairs and Forestry (DWAF). 1999. Quality of Domestic Water Supplies: Sampling Guide. Department of Water Affairs and Forestry, Department of Health and Water Research Commission, Pretoria.

Downson, P., Scrimshaw, M.D., Nasir, J.M., Bubb, J.N. and Lester, J.N. 1996. The environmental impact of a chemical spill from a timber-treatment works on a lowland river system. In: Journal of the Chartered Institution of Water and Environmental Management, Vol. 10, pp. 235-244.

Fakayode, S.O. 2005. Impact assessment of industrial effluent on water quality of the receiving Alaro River, in Ibadan, Nigeria. AJEAM-RAGEE, Vol. 10, pp. 1-13.

Falkenmark, M., Klohn, W., Lundqvist, J., Postel, S., RockstrÖm, J., Seckler, D., Hillel, S. and Wallace, J. 1988. Water scarcity as a key factor behind global food insecurity: Roundable table discussion. Ambio, Vol. 21, No. 2, pp. 148-154.

Gleick, P.H. (ed.). 1993. Water in Crisis. Oxford University Press, New York, USA.

Government of Zimbabwe. 2000. Water (Waste and Effluent Disposal) Regulations, Statutory Instrument 274. Government Printers, Harare.

Harding, W.R., Archibald, C.G.M. and Taylor, J.C. 2005. The relevance of diatoms for water quality assessment in South Africa: a position paper. In: Water SA, Vol. 31, No. 1.

Hirji, R., Johnson, P., Maro, P. and Matiza, T. (Eds). 2002. Defining and Mainstreaming Environmental Sustainability in Water Resources Management in Southern Africa. SADC, IUCN, SARDC, World Bank: Maseru/ Harare/ Washington DC.

Hoehn, R.C. and Sizemore, D.R. 1977. Acid mine drainage and its impact on a small Virginia stream. Water Resources, Vol. 13, pp. 153-160.

Magadza, C. H. D. and Masendu, H. 1986. Some observations on mine effluent in the Yellow Jacket stream, Zimbabwe. The Science News, Vol. 20, pp. 11-28.

Maine, M.A., Suñe, N.L. and Bonetto, C. 2004. Nutrient concentrations in the middle Paraña River: effect of the floodplain lakes. Hydrobiology Vol. 160, pp. 83-103.

Matiza, C.T., Johnson, P. and Hirji, R. 2002. Water and the economy. In: Hirji, R., Johnson, P., Maro, P. and Matiza, T. (Eds). 2002. Defining and Mainstreaming Environmental Sustainability in Water Resources Management in Southern Africa. SADC, IUCN, SARDC, World Bank: Maseru/ Harare/ Washington DC.

Madêra, V., Allen, H.E. and Minear, R.A. 1982. Non-metallic constituents. In: Sues, M.J. (Ed.), Examination of Water for Pollution Control Vol. 2. Chemical and Radiological Examination. Pergamon Press, Oxford.

Moyo, N. A. G., Mazvimavi, D., Mtetwa, S., Dube, B. N., Mhlanga, W. and Mhlanga, A. T. 1998. Water resource. In: Chenje, M., Sola, L. and Paleczny, D. (Eds.), The State of Zimbabwe's Environment 1998. Government of Republic of Zimbabwe. Ministry of Environment and Tourism, Harare.

Moyo, N.A.G. and Worster, K. 1997. The effects of organic pollution on Mukuvisi River, Harare. In: Moyo, N.A.G. (Ed.), Lake Chivero: A Polluted Lake. University of Zimbabwe Publications, Harare.

Nhapi, I. 2005. A 3-step strategic approach to sustainable wastewater management. Water SA, Vol. 31, No. 1, pp. 133-140.

Ometo, J.P.H.B., Martinell, L.A., Ballester, M.V., Gessner, A., Krusche, A.V., Victoria, R.L. and Williams, M. 2000. Effects of land use on water chemistry and macroinvertebrates in two streams of the Piracicaba River basin, Southeast Brazil. Freshw. Biol. Vol. 44, pp. 327-337.

Postel, S.L. 1998. Water for food production: will there be enough in 2025. BioScience, Vol. 48, pp. 629-637.

Rockstrom, J., Gordon, L., Folke, C., Falkenmark and Engwall, M. 1999. Linkages among water vapour flows, food production and terrestrial ecosystem services. Conservation Ecology, Vol. 3, No. 2(5) [online] URL:

http"//www.consecol.org/vol3/iss2/art5.

Schmitz, R.J. 1996. Introduction to Water Pollution Biology. Gulf publishing company, Houston.

Smol, J.P. (ed.). 2002. Pollution of Lakes and Rives: A Paleoenvironmental Perspective. Oxford University Press Inc., New York. 
Welch, P.S. 1948. Limnological Methods. McGraw-Hill Book Co. Inc. Montreal.

Wrobel, L.C. and Latinopoulos, P. (eds.). 1995. Water Pollution III: Modelling, Measuring and Prediction. Computational Mechanics Publications, Boston.

\section{Biographical notes}

Mr. J. R. Chinhanga is currently working as Lecturer at Chinhoyi University of Technology, Zimbabwe. He received his BSc (Hons) in Applied Biochemistry and Masters in Tropical Resources Ecology from National University of Science and Technology, and University of Zimbabwe in October 2001 and October 2005, respectively. His main areas of research interests are aquatic ecology and food product development. Mr. Chinhanga is working on a paper on 'Impact of Effluent from an Iron and Steel Company on Benthic macroinvertebrates composition and distribution along Kwekwe River, Zimbabwe.' He is also writing a paper on Production of a ready-to-eat breakfast food using Ipomoea batatas roots.

Received August 2010

Accepted September 2010

Final acceptance in revised form September 2010 